\title{
Maturity Level of ITSM Analysis Using ITIL v 3 Framework in NLA Purbalingga
}

\author{
Resad Setyadi, Yusmadi Kristian, Afrijal, Farhan Deyantoro, Noto Indra Prakoso \\ Department of Information Systems \\ Telkom Institute of Technology Purwokerto, Indonesia \\ resad@ittelkom-pwt.ac.id
}

\begin{abstract}
The development of communication and information technology impacts the activities and ways of thinking carried out by organizations and governments. The Purbalingga National Land Agency (NLA) is an institution that uses information technology to issue proof of land rights in the agrarian/land and spatial planning sector. This study analyzes IT service management maturity level (ITSM) at NLA Purbalingga using the Information Technology Infrastructure Library (ITIL) V.3 in the operation of domain services. Descriptive analysis method of questionnaires distributed to the community in NLA Purbalingga. The IT maturity level determination at NLA Purbalingga can be done based on the service operation domain factor. The IT maturity level used has five levels for this study. The results of the analysis show that the ITSM maturity level is at level four. Level four means that IT service management at NLA Purbalingga is appropriately handled by paying attention to the factors that are fulfilled according to procedures and taking process actions against systems that are not running effectively. This study aims to provide NLA Purbalingga to improve website maintenance by carrying out comprehensive system integration to enhance work effectiveness and quality.
\end{abstract}

Keywords - Maturity Level, National Land Agency, Service Operation, ITSM, ITIL.

\section{INTRODUCTION}

Information and communication technology will affect organizations, industry, and government [1]. For example, the driving factor for information technology's importance is the increasing need for information technology to improve an organization's service quality [2].

The National Land Agency (NLA) Purbalingga is an organization that utilizes information technology in its organizational activities. It needs good strategic management planning to improve service quality, operational effectiveness, and budget efficiency without reducing the rate [3]. Information technology services at NLA Purbalingga are land services through data validation to input information systems, printing reports, monitoring, etc. By Presidential Regulation of the Republic of Indonesia, Number 17 of 2015 concerning the Ministry of Agrarian and Spatial Planning (MASP) of the Republic of Indonesia has the task of organizing government affairs in the field of agrarian/land and spatial planning to assist the President in carrying out state governance [4]. Meanwhile, the NLA is part of the Ministry of Agrarian and Spatial Planning of the Republic of Indonesia.

From the explanation of the research background, two research questions guide the implementation of the research.

RQ1: What is IT services' maturity level in terms of the operational service domain at the NLA Purbalingga?

RQ2: What recommendations are given based on IT services' maturity level at the NLA Purbalingga?

The research method process takes steps starting from the research procedure, determining and taking data samples, data analysis, discussion, and concluding. The analysis conducted is descriptive and inferential maturity level analysis, limitations, and research recommendations supported by other studies. 


\section{LITERATURE REVIEW}

Public service is an activity or a series of exercises to fulfill service needs following laws and regulations for every citizen and resident for goods, services, and administrative services provided by public service providers [5]. One of the standards developed regarding information technology
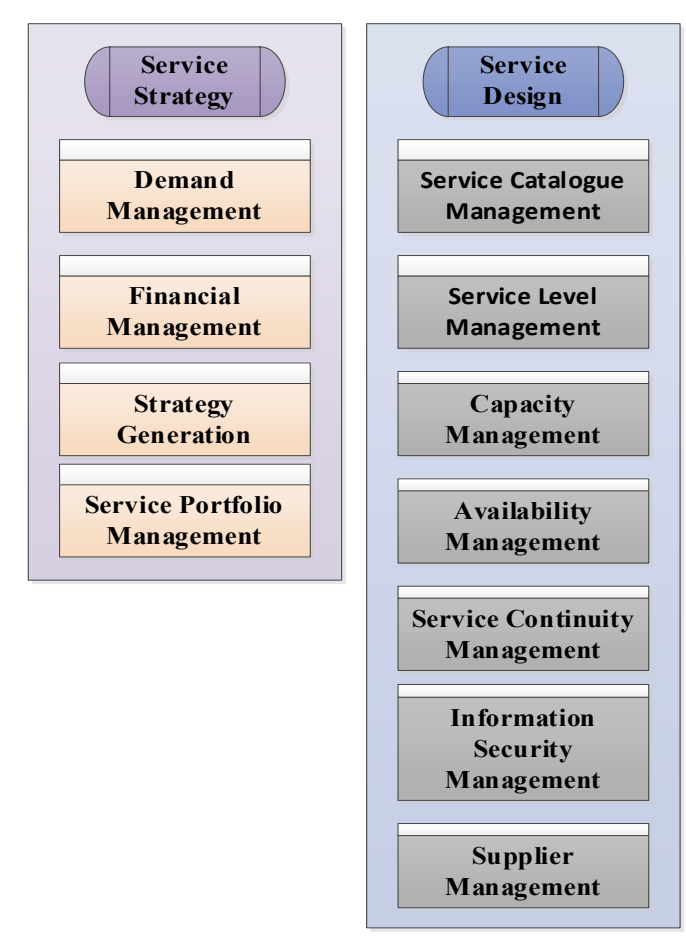

application uses the ITIL standard [6]. ITIL focuses on services for customers in the IT field and improves customer satisfaction by maximizing information service processes and improving information technology services' quality [7]. Fig.1 explains the ITIL v 3 framework.
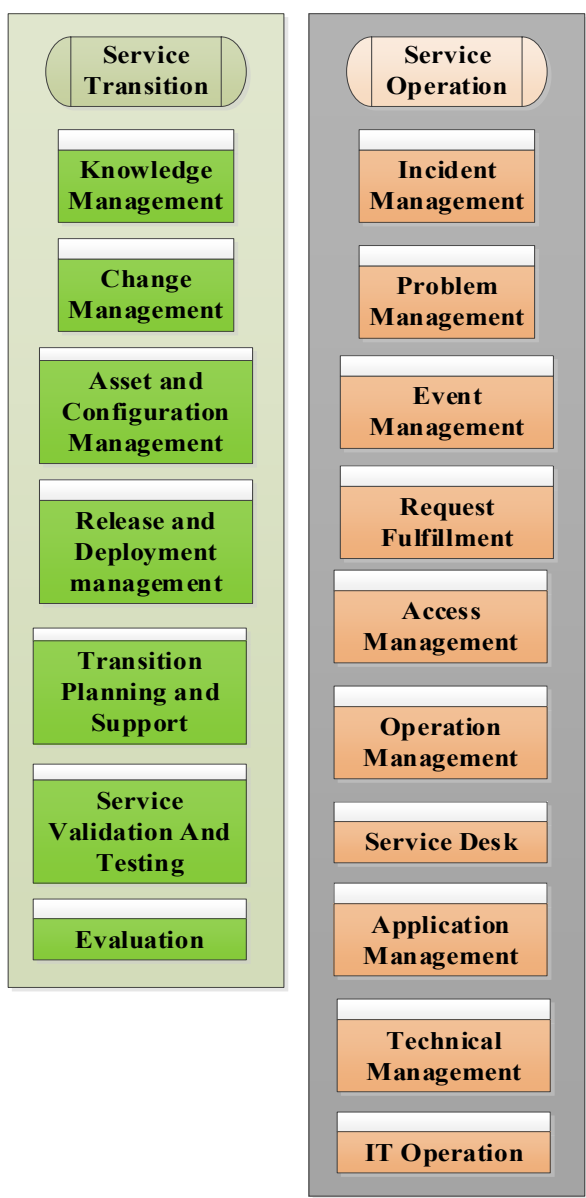

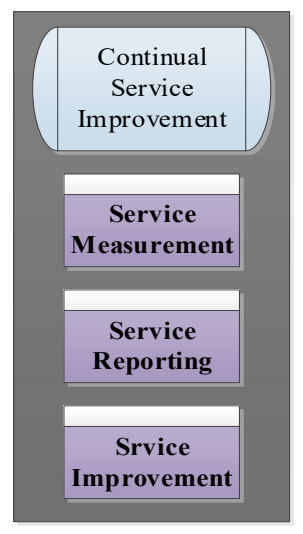

Figure 1. ITIL V3 Framework

ITIL is a series of concepts and techniques. Information technology management, development, and operation are used in ITIL. ITIL v 3 has five domains: Service Strategy, Service Design, Service Transition, Service Operation, and Continual Service Improvement [8].

In this study, the authors use the Domain Service Operation because it follows the ongoing program's information technology conditions. As per the application, the need for land registration up to the land acquisition, serving stakeholders, and supporting sustainable service operations.
The domain of Service Operations is the domain that observes the activities of the day-to-day operational stages of information technology services, including ensuring that users genuinely feel service value [9]. Service operations aim to coordinate and carry out the required service process activities, including managing service agreements for users and customers [10]. Service operations are responsible for managing applications, technology, and infrastructure to support service delivery.

Service operations have the following processes: 


\section{a. Event Management}

Monitor all events throughout the IT infrastructure, monitor normal operations and detect and escalate unwanted conditions.

\section{b. Incident Management}

Concentrate on restoring service downturns or interruptions to users as quickly as possible to minimize the business's impact.

\section{c. Problem Management}

Root cause analysis determines and resolves, prevents, and prevents future problems. This activity is also used to diagnose errors and fix them more quickly if further incidents occur.

\section{d. Request Fulfillment}

The processes for handling service requests are small and low risk, initially by going through the service desk, but using a different method similar to incident management but with another record fulfillment request related to the record of incidents or problems initiated for something requested.

\section{e. Access Management}

The process of granting authorization for users to use services to restrict access from unauthorized users.

The functions covered in service operations include:

\section{a. Service Desk}

The user's primary point of contact when the service is down, service requests, and events requested change. The service desk provides a communication point for users and a coordination point for several IT groups and processes.

\section{b. Technical Management}

Provide detailed technical capabilities and resources needed to support the sustainable operation of the IT infrastructure. Technical management also plays a role in designing, testing, releasing, and improving IT services.

\section{c. IT Operation Management}

Carry out daily operational activities needed to manage IT infrastructure based on standardization during the service design stage.

\section{d. Application Management}

Responsible for managing applications throughout the lifecycle, supporting and managing operational applications, and playing an essential role in designing, testing, and upgrading applications that are part of IT services.

\section{e. Interfaces to Other Service Management Lifecycle Stages}

Some processes are executed or supported during the service operation process but are also driven by other phases in the service life cycle management

Based on the explanation described, the purpose of this study is to measure the maturity level of the use of information systems at the NLA Purbalingga using the Information Technology Infrastructure Library (ITIL) version 3 framework in the operational service sub-domain.

Knowing the maturity level of information systems' use is information recommendations related to IT operational efficiency, improving service quality standards, and increasing service providers' effectiveness and efficiency [11].

The conclusion of the service maturity level for the operational service domain will be recommended for the website-based service system of the NLA Purbalingga and expected to be a reference or guideline for improving information system services.

The maturity level is a system used to measure an organization's maturity process [12]. Organizational maturity refers to the organization's ability to deliver IT services to consumers. The maturity level consists of indicators that show evidence of organizational capabilities. This evaluation assessment uses level 0 (Non-existent) level 5 (optimized). An explanation of the scale $0-5$ is as follows [13].

1. Scale 0.00 - 0.83: Non-Existent, meaning that the company had no IT processes identified at all.

2. Scale 0.84 - 1.66: Initial; this means that the company has started to recognize its information technology process, but it is not 
standardized yet. It is completed separately and does not have an organizational standard. There is evidence that companies are aware of resolved problems that need to be.

3. Scale 1.67-2.49: Repeatable but Intuitive; this means that the company has started using procedures in the information technology process, but there has been no formal training and communication regarding these standard procedures. This process's responsibility still rests with the individual, and the dependence on individual abilities is so high that errors will occur.

4. Scale 2.50 - 3.32: Defined Process; meaning that company procedures have been standardized, documented, and communicated through training, but how the implementation still depends on whether individuals follow the guidelines. The established procedures are not complicated, only the formalization of existing activities.

5. Scale 3.33 - 4.15: Managed and Measurable, meaning that the company can measure and monitor existing procedures so that handling is easy if a violation occurs. The current process is working fine and stable. Use limited automation and information technology tools.

6. Scale 4.16 - 5.00: Optimized; it means that the company, through continuous improvement, has achieved best practice. Information technology has been integrated and used.

Table 1 Maturity Level of ITIL Framework

\begin{tabular}{cl}
\hline Index & \multicolumn{1}{c}{ Level } \\
\hline $0.00-0.83$ & $0 .-$ Non-Existent \\
\hline $0.84-1.66$ & 1.- Initial \\
\hline $1.67-2.49$ & 2.- Repeatable but intuitive \\
\hline $2.50-3.32$ & 3- Defined \\
\hline $3.33-4.15$ & 4.- Managed and Measurable \\
\hline $4.16-5.00$ & 5. - Optimized \\
\hline
\end{tabular}

\section{METHOD}

This study used the research method, starting from observation and distributing questionnaires and data analysis. In the observation process, the authors conducted interviews to determine the initial data on using the system at NLA Purbalingga. Distribution of questionnaires to stakeholders, employees, and consumers with a sample of 80 people from the total population that arrives in one month is 100 people.

This study used the product-moment correlation technique to test validity. The validity test helps know whether the measuring instrument measures what needs to be measured. The writer uses the productmoment method by correlating each question with the total score for each variable. Correlation figures obtained statistically must be compared with the critical statistics of the correlation table of $r$ values with a significant level of $95 \%$. $r$ count $>r$ table means that the data is substantial (valid) and suitable for hypothesis testing. And vice versa if $r$ count $<$ from $r$ table indicates, the data is not significant (invalid) and will not be included in testing the research hypothesis.

$r_{\text {count }}=\frac{n\left(\sum X Y\right)-\left(\sum X\right)\left(\sum Y\right)}{\sqrt{\left(n \sum X^{2}\right)-\left(\sum X\right)^{2}}\left(n \sum y^{2}-\left(\sum Y\right)^{2}\right)} \ldots \ldots$

$\mathrm{r}_{\text {count }}=$ correlation coefficient between $\mathrm{X}$ and Y variables

$\mathrm{N}=$ number of respondents

$\Sigma_{\mathrm{X}}=$ total scores of the items

$\Sigma_{Y}=$ total scores of questions

$\Sigma_{\mathrm{X}}{ }^{2}=$ total score squares of the items

$\Sigma_{\mathrm{Y}}{ }^{2}=$ total score of the squares of the items

For the reliability test, the authors conducted this test to determine whether the data collection tool showed accuracy, accuracy, stability, or consistency in expressing specific symptoms of individuals, even though it was done at different times. Reliability test is carried out on statements that are already valid. This test is carried out using the Cronbach alpha technique because the answer value consists of a range of deals with the larger alpha coefficient. Reliability means trustworthy "That is, the instrument can give the right results. 
$\mathrm{r}_{\text {instrument }}=\left(\frac{n}{n-1}\right)\left(1-\frac{\sum s_{i}^{2}}{\sum s_{t}^{2}}\right)$

$r_{\text {instrument }}=$ reliability of instrument

$\mathrm{n}=$ number of questions

$\mathrm{Si}^{2}=$ variance of item

$\mathrm{s}_{\mathrm{t}}{ }^{2}=$ total variance

The determination of the number of samples comes from the use of the Slovin formula [14].

$\mathrm{n}=\frac{\mathrm{N}}{\mathrm{N}\left(\mathrm{d}^{2}\right)+1}$

$\mathrm{N}=$ population

$\mathrm{n}=$ sample

$\mathrm{d}^{2}=$ significant value $=(0.05)^{2}$

The calculation of the maturity level index uses the weight value for each total sample as in the following explanation:

Index of Maturity Level $=\frac{\mathrm{WV}}{\mathrm{TS}}$

$\mathrm{WV}=$ weight value

$\mathrm{TS}=$ total samples

The calculation of the maturity level average uses the total weight value for each full sub-domain times by total sample as in the following explanation:

Maturity Level Average $=\frac{\mathrm{TWV}}{\mathrm{TSD} \times \mathrm{TS}} \ldots$

TWV $=$ total weight value

$\mathrm{TSD}=$ total subdomains

$\mathrm{TS}=$ total samples

\section{RESULT AND DISCUSSION}

\section{A. Result}

The first step in data analysis is to identify the respondent's profile. In table 2 , questionnaire respondents in the NLAA Purbalingga environment have various education levels, work types, computer skills, and intensity of coming to NLA Purbalingga. Categorization of respondents aims to determine the reliability and validity of the analyzed questionnaire results [15].

Table 2. The Respondent Profile

\begin{tabular}{ccc}
\hline Standard & Indicator & $\mathbf{\%}$ \\
\hline Education level & Diploma & 35 \\
& Associate degree & 11.25 \\
& Bachelor & 46.25 \\
& Magister & 7.5 \\
\hline Job position & Manager NLAA & 3.75 \\
& staff NLAA & 27.5 \\
& private employees & 37.5 \\
& government employees & 18.75 \\
Computer Skill & Less & 18.75 \\
& Enough & 52.5 \\
& Good & 28.75 \\
\hline Coming & $<5$ times & 15 \\
intensity to & $5<$ coming $<10$ times & 53.75 \\
NLA & $>10$ times & 31.25 \\
Purbalingga & & \\
\hline
\end{tabular}

\section{Validity Test}

The data was obtained and inputted into the validity formula for the validity test results, as shown in Table 3 .

Table 3. The Validity Test result

\begin{tabular}{cccc}
\hline Question & $\mathbf{r}_{\text {count }}$ & $\mathbf{r}_{\text {table }}$ & result \\
\hline 1 & 0.915 & 0.220 & Valid \\
\hline 2 & 0.903 & 0.220 & Valid \\
\hline 3 & 0.912 & 0.220 & Valid \\
\hline 4 & 0.885 & 0.220 & Valid \\
\hline 5 & 0.925 & 0.220 & Valid \\
\hline 6 & 0.955 & 0.220 & Valid \\
\hline 7 & 0.925 & 0.220 & Valid \\
\hline 8 & 0.955 & 0.220 & Valid \\
\hline 9 & 0.876 & 0.220 & Valid \\
\hline 10 & 0.910 & 0.220 & Valid \\
\hline
\end{tabular}

\section{Reliability Test}

The results of the reliability test were coming from the research data. It input into the reliability formula as in table 4 .

Table4. The Reliability Test result

\begin{tabular}{cc}
\hline Cronbach Alpha's & N of items \\
\hline .961 & 10 \\
\hline
\end{tabular}

\section{Maturity Test}

The results of the maturity test of IT service management at NLA Purbalingga using the ITIL V3 domain of service Operation measurement tool as in table 5 
Table5. The Maturity Level Test result

\begin{tabular}{|c|c|c|c|c|c|c|c|c|}
\hline \multirow[t]{2}{*}{ No } & \multirow[t]{2}{*}{ SD } & \multicolumn{5}{|c|}{ Weight Value } & \multirow{2}{*}{ W } & \multirow{2}{*}{ ML } \\
\hline & & 1 & 2 & 3 & 4 & 5 & & \\
\hline 1 & EM & 6 & 3 & 41 & 25 & 5 & 260 & 3.25 \\
\hline 2 & IM & 3 & 5 & 38 & 27 & 7 & 270 & 3.38 \\
\hline 3 & PM & & 1 & 36 & 33 & 10 & 292 & 3.65 \\
\hline 4 & $\mathrm{RF}$ & & 2 & 22 & 35 & 21 & 315 & 3.94 \\
\hline 5 & AM & & 3 & 14 & 26 & 37 & 337 & 4.21 \\
\hline 6 & $\mathrm{SD}$ & & 2 & 20 & 23 & 35 & 331 & 4.14 \\
\hline 7 & TM & 4 & 2 & 42 & 25 & 7 & 269 & 3.36 \\
\hline 8 & $\begin{array}{l}\text { IT } \\
\text { OM }\end{array}$ & & 1 & 26 & 21 & 32 & 324 & 4.05 \\
\hline 9 & AM & & 2 & 16 & 29 & 33 & 333 & 4.16 \\
\hline 10 & $\begin{array}{l}\text { I to } \\
\text { OS } \\
\text { M } \\
\text { LS }\end{array}$ & 5 & 13 & 49 & 6 & 7 & 237 & 2.96 \\
\hline & & & Tota & & & & 2968 & 37.1 \\
\hline & & & & rage & & & & 3.71 \\
\hline
\end{tabular}

SD : Subdomain

W : Weight

ML : Maturity Level

EM : Event Management

IM : Incident Management

PM : Problem Management

RF : Request Fulfillment

AM : Access Management

SD : Service Desk

TM : Technical Management

IT OM : IT Operation Management

AM : Application Management

I to OSM LS: Interfaces to Other Service Management Lifecycle Stages

\section{B. Discussion}

The author explains that the respondents' profile aims to show the strength of research data that is trusted, accurate, and accountable [16] The importance of quantitative study and analysis and many methods is also discussed in the literature. Etikan analyzed and compared two nonprobability sampling techniques for quantitative studies [17]. The Slovin formula uses the number of samples from the total population in one month. The use of quantitative methods also pays attention to ethics in research analysis so that ethical quality is also maintained [18]. However, some experts argue: Quantitative research leaves out the meanings and effects of a particular system - such as a testing system is not concerned with the detailed picture of the variable [19]. The analysis of the IT service maturity level of NLA Purbalingga shows that at the level of Managed and Measurable with an average value of 3.71, the NLA can measure and monitor existing procedures that handling is easy if a violation occurs. The current process is working fine and stable. Use limited automation and information technology tools. NLA Purbalingga still has to optimize and improve its IT services quality to reach an IT service management optimization point.

\section{CONCLUSION}

The IT Service Management Maturity Level at NLA Purbalingga is worth 3.71 and is at level 4. It means managed and measurable. The value of 3.71 means that it is in a monitored and quantifiable condition. NLA Purbalingga's recommendation is to improve IT services in terms of practical data access that can be done in a mobile application. The practicality of accessing the NLA Purbalingga website application in a portable manner in managing land certificates will increase NLA Purbalingga's IT service management's effectiveness and efficiency. The suggestion for further research with the NLA Purbalingga object is to add a longer research duration so that monitoring and analysis can be even more accurate. The use of the Continual Service Improvement domain is also necessary for further study.

\section{REFERENCES}

[1] T. Lucio-Nieto and D. L. GonzálezBañales, "Exploring ITIL ${ }^{\circledR}$ implementation challenges in Latin American companies," Int. J. Inf. Technol. Syst. Approach, vol. 12, no. 1, pp. 73-86, 2019, DOI: 10.4018/IJITSA.2019010105.

[2] S. Chatterjee, G. Moody, P. B. Lowry, S. Chakraborty, and A. Hardin, "Information Technology and 
organizational innovation: Harmonious information technology affordance and courage-based actualization," J. Strateg. Inf. Syst., vol. 29, no. 1, p. 101596, 2020, DOI: $10.1016 /$ j.jsis. 2020.101596 .

[3] N. Shin, S. Park, and H. Kim, "Consumer satisfaction-based social commerce service quality management," BRQ Bus. Res. Q., 2020 ,

DOI: $10.1177 / 2340944420916098$.

[4] K. Agraria, "Regulation of the President of the Republic of Indonesia regarding agrarian land, state land and urban spatial planning.," Agrar. J., vol. 8, no. 5, p. 55, 2019.

[5] B. Gumah and M. A. Aziabah, "Our Lives Are Affected by Government Agencies': Citizens' Perception Survey as a Measure of Public Service Efficiency in Ghana," SAGE Open, vol. 10, no. 2, 2020, DOI: $10.1177 / 2158244020935900$.

[6] A. Omar, Z. Peñaherrera, and V. M. P. Osorio, "IT Service Management Model Based on ITIL for the Information Technology and Communications Unit of the Universidad de las Fuerzas Armadas ESPE Campus Latacunga," vol. 11, no. 6, pp. 170-175, 2020, DOI: 10.18178/ijimt.2020.11.6.898.

[7] P. Quiroz-Palma, A. Suárez-Alarcón, A. Santamaría-Philco, W. Zamora, V. Garcia, and E. Vera-Burgos, "ITSIM : Methodology for Improving It," in ICITS, 2019, vol. 2, pp. 199-209, DOI: 10.1007/978-3-030-11890-7.

[8] N. J. Cruz-Hinojosa and J. A. Gutiérrez-De-Mesa, "Literature review of the situation research faces in the application of ITIL in Small and Medium Enterprises," Comput. Stand. Interfaces, vol. 48, pp. 124-138, 2016, DOI: $10.1016 /$ j.csi.2016.05.001.

[9] J. Jayaram and K. Xu, "Determinants of quality and efficiency performance in service operations," Int. J. Oper. Prod. Manag., vol. 36, no. 3, pp. 265-
285, 2016, DOI: 10.1108/IJOPM-032014-0122.

[10] A. Krishna Kaiser, "Become ITIL Foundation Certified in 7 Days," in Become ITIL Foundation Certified in 7 Days, 2017, pp. 33-44.

[11] H. Woo, S. Lee, J.-H. Huh, and S. Jeong, "Impact of ITSM Military Service Quality and Value on Service Trust," J. Multimed. Inf. Syst., vol. 7, no. 1, pp. 55-72, 2020, DOI: 10.33851/jmis.2020.7.1.55.

[12] R. B. Dayal and R. C. Kushwaha, "Deep analysis of ITIL framework for improvement of indian IT services in industries," Eur. J. Mol. Clin. Med., vol. 7, no. 4, pp. 2243-2249, 2020.

[13] O. Alshathry, "Maturity Status of ITIL Incident Management Process among Saudi Arabian Organizations," Int. J. Appl. Sci. Technol., vol. 6, no. 1, pp. 40-46, 2016, [Online]. Available: http://www.ijastnet.com/journals/Vol_6 No_1_February_2016/7.pdf.

[14] $\bar{A} . \quad \bar{M}$. Adam, "Sample Size Determination in Survey Research," J. Sci. Res. Reports, vol. 26, no. 5, pp. 90-97, 2020, DOI: 10.9734/jsrr/2020/v26i530263.

[15] P. Madzík and A. Shahin, "Customer categorization using a threedimensional loyalty matrix analogous to FMEA," Int. J. Qual. Reliab. Manag., 2020, DOI: 10.1108/IJQRM05-2020-0179.

[16] A. Queirós, D. Faria, F. Almeida, I. Superior, and P. Gaya, "Strengths and Limitations of Qualitative and Quantitative Research Methods Innovation and Entrepreneurship View project Observatory of Portuguese Academic Spin-offs View project European Journal of Education Studies STRENGTHS AND LIMITATIONS OF QUALITATIV," pp. 369-387, 2017, DOI: $10.5281 /$ zenodo.887089.

[17] I. Etikan, "Sampling and Sampling Methods," Biometrics Biostat. Int. J., vol. 5, no. 6, pp. 5-7, 2017, DOI: 10.15406/bbij.2017.05.00149. 
[18] M. J. Zyphur and D. C. Pierides, "Is Quantitative Research Ethical? Tools for Ethically Practicing, Evaluating, and Using Quantitative Research," J. Bus. Ethics, vol. 143, no. 1, pp. 1-16, 2017, DOI: $10.1007 / \mathrm{s} 10551-017-3549-$ 8.

[19] M. S. Rahman, "The Advantages and Disadvantages of Using Qualitative and Quantitative Approaches and Methods in Language 'Testing and Assessment' Research: A Literature Review," J. Educ. Learn., vol. 6, no. 1, p. 102, 2016, DOI: 10.5539/jel.v6n1p102. 